\title{
Influence of Calcium Sources and Concentration on the Storage Performance of Strawberry Fruit
}

\author{
Ijaz Akhtar ${ }^{1}$ and Abdur Rab ${ }^{2}$ \\ 1. Directorate of Agriculture Research, Peshawar 25000, Pakistan \\ 2. Department of Horticulture, the University of Agriculture, Peshawar 25000, Pakistan
}

Received: June 3, 2014 / Published: August 20, 2014.

\begin{abstract}
Chemical application after harvest is an important method to preserve strawberry fruit quality and extend shelf life. The strawberry fruits harvested at red stage were treated with three different sources of calcium, i.e., calcium nitrate, calcium gluconate and calcium chloride at calcium concentration of $0 \%$ (distilled water), $0.5 \%, 1.0 \%$ and $1.5 \%$. The strawberry fruits were dipped for $30 \mathrm{~s}$. The calcium sources, calcium concentration and the interaction of calcium sources and calcium concentration significantly affected the storage performance of strawberry fruits. All the three sources and concentrations were effective in decreasing the storage associated changes, i.e., weight loss, decline in marketable fruits, loss of organoleptic quality, increase in total soluble solids (TSS), decline in reducing sugars, total sugars, acidity and increase in sugar/acid ratio in strawberry fruit, thus extending the shelf life. Calcium gluconate at $1.5 \%$ calcium concentration was more effective. Treatment of strawberry fruit with $1.5 \%$ calcium from calcium gluconate source resulted in the highest number of marketable fruit (100\%), extended shelf life (10 d), and total soluble solid (7.80\%) with the minimum weight loss (5.45\%). Calcium dips result in higher calcium concentration in strawberry fruits, which delays ripening in fruits by maintaining the structure and function of cell walls and membranes. It can be concluded that calcium gluconate at $1.5 \%$ concentration is an effective calcium treatment to retain the quality and extend the shelf life of strawberry fruit.
\end{abstract}

Key words: Calcium, concentrations, fruit, perishable, salts, sources, storage, strawberry.

\section{Introduction}

The strawberry (Fragaria $\times$ ananassa Duch.) fruits are highly perishable due to high respiration, soft skin and high moisture content and rapid weight loss [1, 2]. The post harvest life of strawberry fruit is very short (one to two days) at room temperature [1]. Strawberry is also very susceptible to mechanical injuries, decay and physiological deterioration after harvest, which reduces the profit margin of the stakeholders [3]. Thus, the postharvest handling plays a very important role in shelf life of strawberry fruit [4]. An efficient postharvest management is essential to preserve the

Corresponding author: Ijaz Akhtar, assistant director planning, research field: horticulture. E-mail: ijazakh@hotmail.com. fruit quality [5]. The storage life of strawberry fruits can be extended by various treatments and techniques such as pre cooling [6], waxing [7], coating [8] and chemical application [9] combined with refrigeration $[6,10]$.

Many types of chemicals/waxes are applied to fruits and vegetables after harvest to decrease the rate of metabolism, water loss, control diseases [7] and physiological disorders [11]. In strawberry, different types of calcium salts are commonly used for the maintenance of quality and shelf life [12]. The most commonly used calcium sources are calcium nitrate $\left(\mathrm{Ca}\left(\mathrm{NO}_{3}\right)_{2}\right)$, calcium gluconate $\left(\mathrm{C}_{12} \mathrm{H}_{22} \mathrm{CaO}_{14}\right)$ and calcium chloride $\left(\mathrm{CaCl}_{2}\right)$ [13]. Calcium application is reported to increase the shelf life of various fruits and vegetables $[9,14]$. 
The application of calcium to fruits and vegetables delays ripening, reduces postharvest decay and controls the development of various physiological disorders, thus improving their nutritional value [11, 15, 16]. Different concentration of calcium salts and ascorbic acid extend the shelf life of strawberry fruit [13]. Calcium treated strawberry fruits retain sugars and organic acids during cold storage as well as retain fruit firmness and texture [12] by decreasing the rate of respiration and ethylene production [17]. Besides, calcium application may delay fruit ripening and senescence by delaying cell wall breakdowns associated with fruit softening [18].

The strawberry fruit is also sensitive to several fungal diseases such as Rhizopus rot, leather rot $[4,19]$ and grey mold [20, 21]. The application of calcium also decreases storage breakdown and rots [22] by improving resistance to fungal attack [23]. There are limited processing facilities in Pakistan, due to which most of the fruits, including strawberry are marketed in fresh form [24]. In the peak production season, bulk of fruits are produced which ultimately lower the price [25]. Since strawberry fruit is highly perishable [26], post harvest management, including chemical treatment [20], storage at low temperature with proper humidity and use of improved packing material can be effective to reduce post harvest losses and increase the shelf life [27]. Calcium application retains fruit quality $[9,14]$. The present study was conducted to find out the influence of different calcium sources and calcium concentration on the quality and post harvest performance of strawberry fruit and to optimize the calcium sources and concentration for strawberry fruits, which may help in retaining the quality and extending the shelf life of strawberry fruit during storage.

\section{Materials and Methods}

The influence of calcium sources and concentrations on the storage performance of strawberry fruit was investigated at Post Harvest
Laboratory, Department of Horticulture, the University of Agriculture, Peshawar, Pakistan during the year 2007-2008.

\subsection{Methodology}

The experiment was laid out in completely randomized factorial design (CRFD) with two factors and three repeats.

\subsubsection{Plant Material}

The Chandler strawberries were grown at district Charsadda, Khyber Pakhtunkhwa. The fruits were harvested at a uniform maturity i.e., red stage. Fifty fruits (with calyx) were selected for each treatment and replication. The fruits were dipped for $30 \mathrm{~s}$ in each calcium salt solution having different concentration. Calcium solutions were prepared from three calcium sources i.e., calcium nitrate, calcium gluconate and calcium chloride with four calcium concentrations, i.e., $0 \%$ (distilled water), $0.5 \%, 1.0 \%$ and $1.5 \%$. The surface moisture of the treated fruits was dried with a gentle air blower. The treated strawberry fruits were stored for eight days in perforated plastic packages (18 perforations of $0.5 \mathrm{~cm}$ diameter) of size $(20 \mathrm{~cm} \times 15 \mathrm{~cm})$ at $5{ }^{\circ} \mathrm{C} \pm 2{ }^{\circ} \mathrm{C}$ and $90 \%$ RH (relative humidity) and evaluated for different physical and chemical quality attributes after storage.

\subsubsection{Weight Loss (\%)}

The weight loss of the fruits was estimated by weighing $250 \mathrm{~g}$ fruit treated with different calcium salts and respective concentrations. The initial weight of the samples was recorded. The samples were then stored at $5{ }^{\circ} \mathrm{C} \pm 2{ }^{\circ} \mathrm{C}$ and $90 \% \mathrm{RH}$ for $8 \mathrm{~d}$. The fruit were weighed again after storage and the weight loss was determined by the following formula:

Weight loss (\%) $=\frac{\text { Loss of sampleweight }}{\text { Weight of sample }} \times 100(1)$

\subsubsection{Marketable Fruits (\%)}

The marketable fruits (\%) were estimated by counting the number of attractive and disease free fruit 
after storage and the percentage calculated as given in the following formula:

Marketable fruits $(\%)=$

$$
\frac{\text { Number of marketable fruits }}{\text { Total number of fruits }} \times 100
$$

\subsubsection{Shelf Life}

To determine the influence of calcium sources and its concentration on the shelf life of strawberry fruits, a separate set of 50 fruits with calyx were stored as described above. The shelf life (days) was determined by observing the desirable fruit (solid, firm, fresh and attractive looking) daily. A base line, i.e., 15\% loss in desirable fruit was considered as the maximum shelf life.

\subsubsection{Organoleptic Evaluation}

Organoleptic evaluation of strawberry fruits was conducted after eight days storage by a panel of judges for fruit qualities as color, taste, aroma, texture and overall acceptability as described by Larmond [28]. Scores were assigned to samples from one to nine according to fruit quality, with nine representing like extremely and one for dislike extremely.

\subsubsection{Total Soluble Solids (TSS) (\%)}

The TSS contents of strawberry fruits were determined after storage by using a hand refractometer (Kernco, Instrument Co, Texas) according to the method as described by the AOAC (association of official analytical chemist) [29].

\subsubsection{Total Sugars (\%)}

Reducing and non reducing sugars were determined after storage by Lane Eynon method as reported by the AOAC [29].

\subsubsection{Titratable Acidity (\%)}

Percent acidity of strawberry fruit was determined after storage by acid neutralization method as reported [29].

\subsubsection{Sugar/Acid Ratio}

The sugar acid ratio of strawberry fruits after storage was calculated by the following formula:

$$
\text { Sugar/acid ratio }=\frac{\text { Total sugars }}{\text { Titratable acidity }}
$$

2.1.10 Vitamin C (mg/100 g)

Vitamin C (ascorbic acid) after eight days storage was calculated by Titrimatric method as described by AOAC [29].

\subsection{Data Analysis}

The experiment was laid out in two-factorial completely randomized design (CRD) with different calcium sources (factor A) and their concentrations (factor B). The data based on different parameters of strawberry fruits harvested at uniform maturity, treated with different types of calcium sources and concentrations were subjected to analysis of variance (ANOVA) technique. In cases where the differences were significant, the means were further assessed for differences through least significant difference (LSD) test. Statistical computer software, Statistix-9 (USA) was applied for computing both the ANOVA and LSD.

\section{Results and Discussion}

\subsection{Weight Loss (\%)}

Calcium salts and concentrations as well as the interaction of calcium salts and calcium concentrations significantly affected the weight loss of strawberry fruit. The mean minimum weight loss (8.44\%) was recorded in fruits treated with calcium gluconate, followed by $8.64 \%$ with calcium chloride with the difference being non significant, while the maximum mean weight loss (10.63\%) was recorded in fruits treated with calcium nitrate. The calcium concentration also significantly affected the weight loss of strawberry fruit with the minimum weight loss (5.95\%) in fruits treated with $1.5 \%$ calcium, followed by $9.03 \%$ with $1.0 \%$ calcium, while the maximum weight loss (11.90\%) was in fruits treated with distilled water (Table 1). The interaction of calcium salts and concentration revealed the minimum weight loss $(5.45 \%)$ when strawberry fruits were treated with calcium gluconate at $1.5 \%$, followed by $5.84 \%$ with calcium chloride at $1.5 \%$ with the difference being 
Table 1 Effect of calcium salts and concentration on the physical quality of strawberry at storage.

\begin{tabular}{|c|c|c|c|c|}
\hline Calcium salts & Weight loss (\%) & Marketable fruit (\%) & Shelf life (days) & Organoleptic evaluation \\
\hline Calcium nitrate & $10.63^{\mathrm{a}}$ & $92.75^{\mathrm{b}}$ & $6.00^{\mathrm{b}}$ & $5.00^{\mathrm{b}}$ \\
\hline Calcium gluconate & $8.44^{\mathrm{b}}$ & $94.63^{\mathrm{a}}$ & $7.00^{\mathrm{a}}$ & $6.00^{\mathrm{a}}$ \\
\hline Calcium chloride & $8.64^{\mathrm{b}}$ & $89.33^{\mathrm{c}}$ & $6.00^{\mathrm{b}}$ & $6.00^{\mathrm{a}}$ \\
\hline $\operatorname{LSD}_{(0.05)}$ & 0.28 & 1.61 & 0.90 & 0.35 \\
\hline \multicolumn{5}{|c|}{ Calcium concentration (\%) } \\
\hline 0 & $11.90^{\mathrm{a}}$ & $86.07^{\mathrm{d}}$ & $5.00^{\mathrm{C}}$ & $5.00^{\mathrm{C}}$ \\
\hline 0.5 & $10.06^{\mathrm{b}}$ & $90.22^{\mathrm{c}}$ & $5.00^{\mathrm{c}}$ & $5.00^{\mathrm{C}}$ \\
\hline 1.0 & $9.03^{\mathrm{c}}$ & $95.00^{\mathrm{b}}$ & $7.00^{\mathrm{b}}$ & $6.00^{\mathrm{b}}$ \\
\hline 1.5 & $5.95^{\mathrm{d}}$ & $97.66^{\mathrm{a}}$ & $8.00^{\mathrm{a}}$ & $7.00^{\mathrm{a}}$ \\
\hline $\operatorname{LSD}_{(0.05)}$ & 0.33 & 1.86 & 0.95 & 0.40 \\
\hline \multicolumn{5}{|c|}{ Calcium salts $\times$ calcium concentration } \\
\hline $\operatorname{LSD}_{(0.05)}$ & 0.57 & 3.23 & 1.07 & NS \\
\hline $\mathrm{S} \times \mathrm{C}$ & *Fig. 1a & *Fig. 1b & *Fig. 1c & ----- \\
\hline
\end{tabular}

Means followed by similar letter(s) in column do not differ significantly from one another at $P=0.05$; $*$ significant, $\mathrm{S} \times \mathrm{C}=$ interaction of calcium salts and calcium concentration. $\mathrm{NS}=$ non significant, $\operatorname{LSD}_{(0.05)}=$ Least significant difference at probability level 0.05.

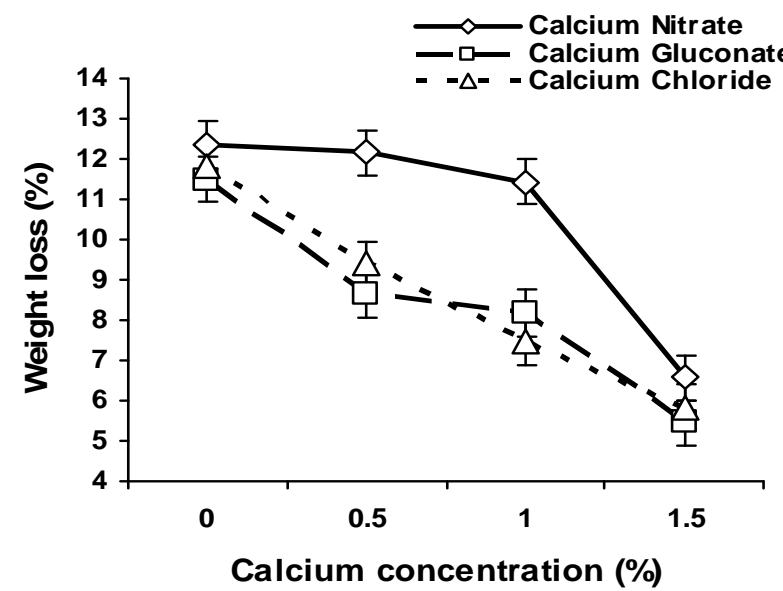

(a)

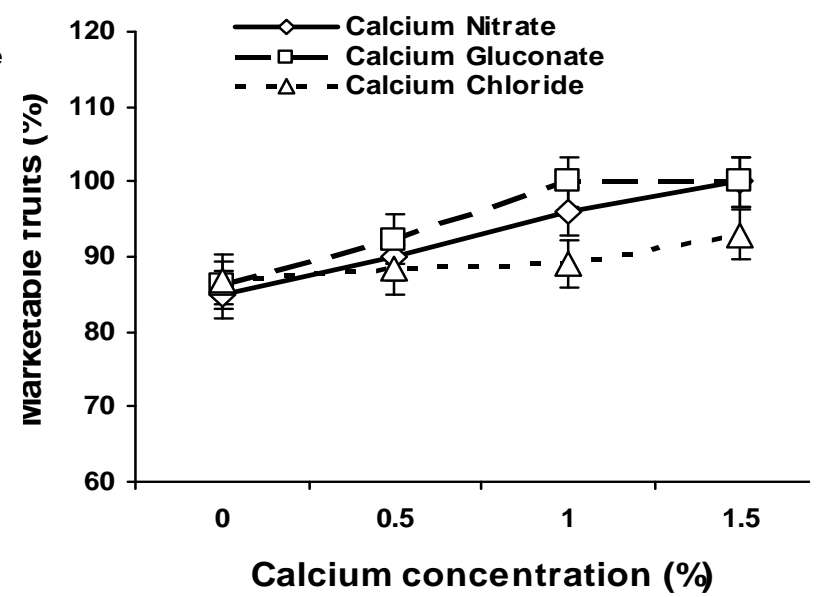

(b)

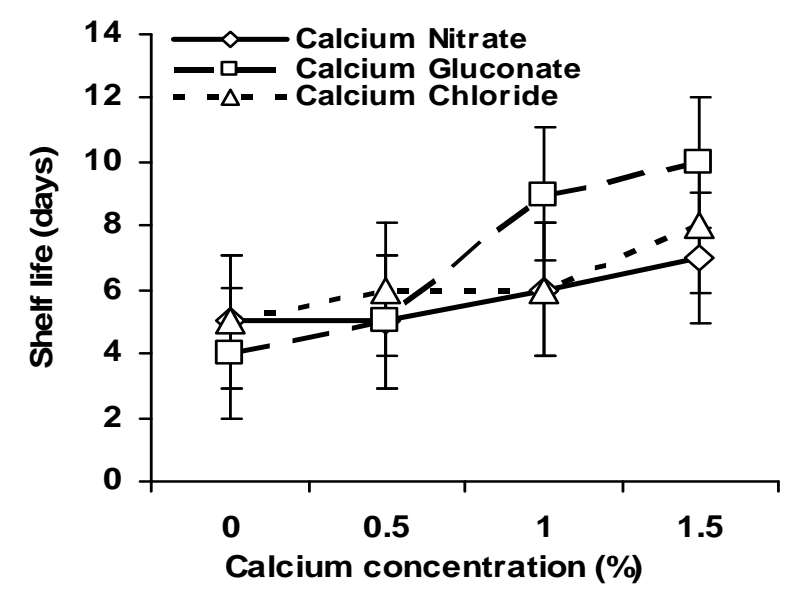

(c)

Fig. 1 (a) Weight loss (\%), (b) marketable fruits (\%) and (c) shelf life (days) of strawberry fruits.

As treated with calcium nitrate, calcium gluconate and calcium chloride with $0 \%, 0.5 \%, 1.0 \%$ and $1.5 \%$ calcium concentration. Error bars represent $\operatorname{LSD}_{(0.05)}$. 
non significant. The maximum weight loss was $12.36 \%$ in strawberry fruits treated with distilled water (Fig. 1a). Weight loss normally occurs during fruit storage due to respiration, transpiration and some processes of oxidation [30,31]. The strawberry is highly perishable fruit due to high respiration rate and rapid weight loss during storage [2]. The mean weight loss also declined with increasing calcium concentration. The maximum mean weight loss observed in control ( $0 \%$ calcium) declined with increase of calcium concentration to the minimum with $1.5 \%$ calcium concentration. The interaction of calcium sources and concentrations revealed that application of calcium from different sources decreased the weight loss, and the maximum decrease in weight loss was recorded with calcium gluconate [20] at concentration of $1.5 \%$ probably due to delaying enzymatic activities responsible for moisture loss and senescence [1]. The superior performance of calcium gluconate in decreasing weight loss can be attributed to its hydrophobic nature, which improves the water vapor barrier by providing hydrophobicity to the surface [32].

\subsection{Marketable Fruits (\%)}

Different types of calcium salts, calcium concentrations and their interaction significantly affected the number of marketable fruits during storage. The mean maximum desirable fruits (94.63\%) were recorded when strawberry fruits were treated with calcium gluconate, followed by $92.75 \%$ with calcium nitrate, while the minimum (89.33\%) was recorded in fruits treated with calcium chloride. Calcium concentration also significantly affected the number of marketable fruit, with the mean maximum (97.66\%) recorded when strawberry fruits were treated with $1.5 \%$ calcium, followed by $95.00 \%$ with $1.0 \%$ calcium while the minimum (86.07\%) marketable fruits were recorded when fruits were treated with distilled water (Table 1). The interaction of calcium salts and calcium concentration also significantly affected the number of marketable fruits. The highest marketable fruits (100\%) was recorded when fruits were treated with calcium nitrate and calcium gluconate at concentrations of $1.5 \%$ but calcium gluconate was equally effective at $1.0 \%$. Fruits treated with distilled water had the least number (85.00\%) of marketable fruits recorded (Fig. 1b). Calcium is an essential component for cell function and tissue integrity [9]. Calcium application is recommended for maintaining the post harvests quality of fruits because it retard softening, deterioration rate and extend post harvest life [20, 33-35]. Among the various calcium salts under study, calcium gluconate resulted in the highest desirable fruits, followed by calcium nitrate while the least desirable fruits were recorded with calcium chloride. It might be due to the reason that calcium gluconate make a film on surface and, thus, act as a barrier to water loss as well as the presence of glucose [32]. Since high respiration results in loss of sugars which is an important factor in perishability of strawberry fruits [2], the presence of glucose in calcium gluconate may contribute toward delaying senescence [1]. Thus, calcium gluconate was more effective than other calcium sources under study [36]. The greater effectiveness of calcium gluconate is also evident from the observation that it was equally effective at concentration of $1.0 \%$ and $1.5 \%$. By contrast, the effectiveness of all the salts increased with increasing calcium concentration to $1.5 \%$. The greater effectiveness of high salt concentration could be attributed to increased calcium absorption at high concentration [37]. It has also been reported that treatment of strawberry fruit with calcium salts increase calcium content in the cell wall of the fruit tissue, which may contribute to retaining the fruit firmness and quality [8]. Lowest marketable fruits were recorded at control while the highest marketable fruits recorded at these interactions may be due to the reasons that combine effect of calcium salts and their concentrations responded better in controlling post harvest losses of 
strawberry fruits during storage $[17,18]$.

\subsection{Shelf Life (Days)}

The shelf life of strawberry fruits was significantly affected by the application of calcium salts, their concentration and the interaction of salts and calcium concentration. The mean maximum shelf life of strawberry fruits (7 d) was recorded when fruits were treated with calcium gluconate, followed by $6 \mathrm{~d}$ in fruits treated with calcium chloride and calcium nitrate. The calcium concentration also significantly affected the shelf life of strawberry fruits with the maximum shelf life $(8 \mathrm{~d})$ recorded with $1.5 \%$ calcium treatment, followed by $7 \mathrm{~d}$ with $1.0 \%$ calcium treatment while the minimum (5 d) was recorded when fruits were treated with $0 \%$ calcium (Table 1). The interaction of calcium salts and concentrations revealed that the shelf life of strawberry fruits increased from the minimum (5 d) in control to the maximum $(10 \mathrm{~d})$ followed by $9 \mathrm{~d}$ in fruits treated with calcium gluconate at $1.5 \%$ and $1.0 \%$, respectively (Fig. 1c). Calcium application is providing a significant impact on the shelf life of various fruits and vegetables [9]. It is clear that calcium salts slow down softening, deterioration rates and prolong shelf life of strawberry fruits $[13,23,26,33]$. The significantly superior performance of calcium gluconate confirms the reports that it is more appropriate source of calcium [32]. External calcium application to strawberry fruit at higher calcium levels $(1.5 \%)$ is more effective, which result in the maximum mean shelf life, probably by increasing the absorption of calcium by strawberry fruits [37]. Since calcium strengthens the fruit cell wall, its higher concentration maintains fruit firmness and quality [8]. In interaction treatments, calcium gluconate at $1.5 \%$ concentration increased the shelf life to $10 \mathrm{~d}$. Shelf life of strawberry fruit can be increased by scientific post harvest handling including calcium treatment [38]. Calcium application decreases storage breakdown and rot and hence prolong the shelf life [22].

\subsection{Organoleptic Evaluation}

Calcium salts and their concentration significantly affected the organoleptic quality of strawberry fruits. The interaction of salts and calcium concentrations was not significant. The highest organoleptic quality score (6) was recorded for fruits treated with calcium gluconate and calcium chloride while the minimum score (5) was recorded with calcium nitrate treatment. The influence of calcium concentration was also significant with the maximum (7) organoleptic quality score with $1.5 \%$ calcium treatment, followed by (6) with $1.0 \%$ calcium treatment as compared to (5) score in control fruits (Table 1). The fruit size, appearance, color, texture, flavor and aroma are important sensory attributes of the strawberry fruit [39] and generally evaluated during organoleptic quality scoring [40]. Since, calcium application maintains fruit quality during storage [41-43]. It is likely to observe higher quality score in calcium treated fruit. However, the increase in quality score with increasing calcium concentration indicates that the influence of calcium is concentration dependent [17]. The incorporation of calcium into the fruit cell wall confers resistance to pathogens [44]. Hence, fruit treated with optimum concentration of calcium shows no visual signs of infection [1]. However, the superior influence of calcium gluconate as compared to other salts could be due to the presence of glucose that retains the quality of strawberry fruit [32].

\subsection{Total Soluble Solids (\%)}

Calcium salts, its concentrations and the interaction of calcium salts and concentrations significantly affected the TSS of strawberry fruits. Fruits treated with calcium chloride had the highest TSS (8.49\%), followed by $8.41 \%$ with calcium gluconate treatment. The least TSS (8.31\%) was in fruits treated with calcium nitrate. The calcium concentrations also significantly affected the TSS contents of strawberry 
fruit with the minimum (7.93\%) with $1.5 \%$ calcium concentration, followed by $8.20 \%$ with $1.0 \%$ calcium treatment, while the maximum mean TSS of strawberry fruits $(9.17 \%)$ was in fruits treated with distilled water (Table 2). The interaction of calcium salts and calcium concentration significantly affected the TSS content of strawberry fruits. Calcium gluconate at $1.5 \%$ calcium concentration resulted in the least TSS (7.80\%), followed by $8.10 \%$ with calcium nitrate at concentration of $1.0 \%$, while the highest TSS (9.20\%) was recorded with $0 \%$ calcium concentration (distilled water) which was similar to other calcium salts used in the study (Fig. 2a). The minimum TSS with calcium gluconate can be due to its film forming properties which decrease moisture loss, and thus, retain the TSS concentration [32]. The TSS content generally increases ripening of the fruit [35], in part due to the solubilization of the cell wall polyuronides and hemicelluloses in mature strawberry fruit [19]. Calcium dips result in higher calcium concentration in strawberry fruits [45]. Since calcium delays ripening in fruits [16] by maintaining the structure and function of cell walls and membranes [45], the minimum TSS recorded in fruits treated with $1.5 \%$ calcium concentration may be due to the inhibition of fruit ripening [4].

\subsection{Reducing Sugars (\%)}

Different calcium salts, calcium concentration and the interaction of calcium salts and its concentrations significantly affected the reducing sugars contents of strawberry fruits. Reducing sugars were the minimum (4.97\%) in fruits treated with calcium chloride, followed by $5.66 \%$ with calcium gluconate treatment, while the maximum (6.21\%) was recorded in fruits treated with calcium chloride. Calcium concentration of $1.5 \%$ resulted in the least reducing sugars (3.97\%) which increased with decreasing calcium to the maximum (7.48\%) in strawberry fruits treated with distilled water (Table 2). The interaction of calcium salts and their concentrations revealed the least reducing sugars $(3.13 \%)$ in strawberry fruits treated with $1.5 \%$ calcium chloride, followed by $3.87 \%$ recorded with $1.0 \%$ calcium chloride, while the highest reducing sugars (7.84\%) was recorded in fruit treated with $0 \%$ calcium nitrate (distilled water), that was similar to other calcium salts (Fig. 2b). Glucose and fructose are the main reducing sugars of strawberry fruit and its concentration increases during storage [46, 47] due to conversion of sucrose to glucose and fructose [48]. The minimum reducing sugars recorded in fruits treated with $1.5 \%$ calcium concentration and the maximum in fruits treated with

Table 2 Effect of calcium salts and concentration on the chemical quality of strawberry at storage.

\begin{tabular}{|c|c|c|c|c|c|c|}
\hline Calcium salts & $\begin{array}{l}\text { Total soluble } \\
\text { solids (\%) }\end{array}$ & $\begin{array}{l}\text { Reducing } \\
\text { sugars (\%) }\end{array}$ & $\begin{array}{l}\text { Total sugars } \\
(\%)\end{array}$ & $\begin{array}{l}\text { Titratable } \\
\text { acidity (\%) }\end{array}$ & Sugar acid ratio & $\begin{array}{l}\text { Ascorbic acid } \\
(\mathrm{mg} / 100 \mathrm{~g})\end{array}$ \\
\hline Calcium nitrate & $8.31^{\mathrm{b}}$ & $6.21^{\mathrm{a}}$ & $8.25^{\mathrm{a}}$ & 1.63 & $5.23^{\mathrm{a}}$ & $32.99^{\mathrm{a}}$ \\
\hline Calcium gluconate & $8.41^{\mathrm{a}}$ & $5.66^{\mathrm{b}}$ & $7.22^{\mathrm{b}}$ & 1.69 & $4.65^{\mathrm{b}}$ & $25.58^{\mathrm{C}}$ \\
\hline Calcium chloride & $8.49^{\mathrm{a}}$ & $4.97^{\mathrm{c}}$ & $6.89^{c}$ & 1.65 & $4.44^{\mathrm{c}}$ & $29.50^{\mathrm{b}}$ \\
\hline $\operatorname{LSD}_{(0.05)}$ & 0.09 & 0.14 & 0.06 & N.S & 0.18 & 1.04 \\
\hline \multicolumn{7}{|c|}{ Calcium concentration (\%) } \\
\hline 0 & $9.17^{\mathrm{a}}$ & $7.48^{\mathrm{a}}$ & $9.60^{\mathrm{a}}$ & $1.38^{\mathrm{C}}$ & $6.92^{\mathrm{a}}$ & $28.50^{\mathrm{b}}$ \\
\hline 0.5 & $8.31^{\mathrm{b}}$ & $6.10^{\mathrm{b}}$ & $7.74^{\mathrm{b}}$ & $1.49^{\mathrm{b}}$ & $5.20^{\mathrm{b}}$ & $28.13^{\mathrm{b}}$ \\
\hline 1.0 & $8.20^{\mathrm{C}}$ & $4.91^{\mathrm{c}}$ & $6.17^{\mathrm{C}}$ & $1.54^{\mathrm{b}}$ & $4.35^{\mathrm{c}}$ & $29.12^{\mathrm{b}}$ \\
\hline 1.5 & $7.93^{\mathrm{d}}$ & $3.97^{\mathrm{d}}$ & $5.75^{\mathrm{d}}$ & $2.21^{\mathrm{a}}$ & $2.61^{\mathrm{d}}$ & $31.69^{\mathrm{a}}$ \\
\hline $\operatorname{LSD}_{(0.05)}$ & 0.10 & 0.16 & 0.07 & 0.07 & 0.21 & 1.21 \\
\hline \multicolumn{7}{|c|}{ Calcium salts $\times$ calcium concentration } \\
\hline $\operatorname{LSD}_{(0.05)}$ & 0.18 & 0.28 & 0.12 & 0.13 & 0.36 & 2.09 \\
\hline $\mathrm{S} \times \mathrm{C}$ & *Fig. 2a & *Fig. 2b & *Fig. 2c & *Fig. 2d & *Fig. 2e & *Fig. 2f \\
\hline
\end{tabular}

Means followed by similar letter(s) in column do not differ significantly from one another at $P=0.05 . *=$ significant, NS $=$ non significant, $\mathrm{S} \times \mathrm{C}=$ interaction of calcium salts and calcium concentration. 


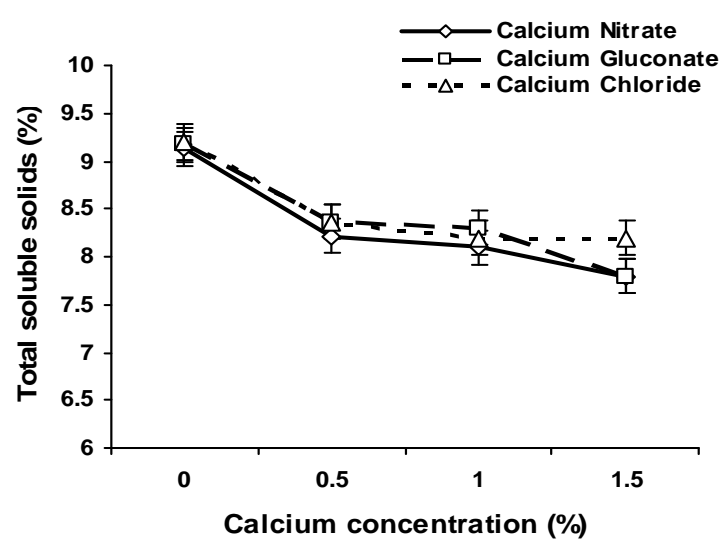

(a)

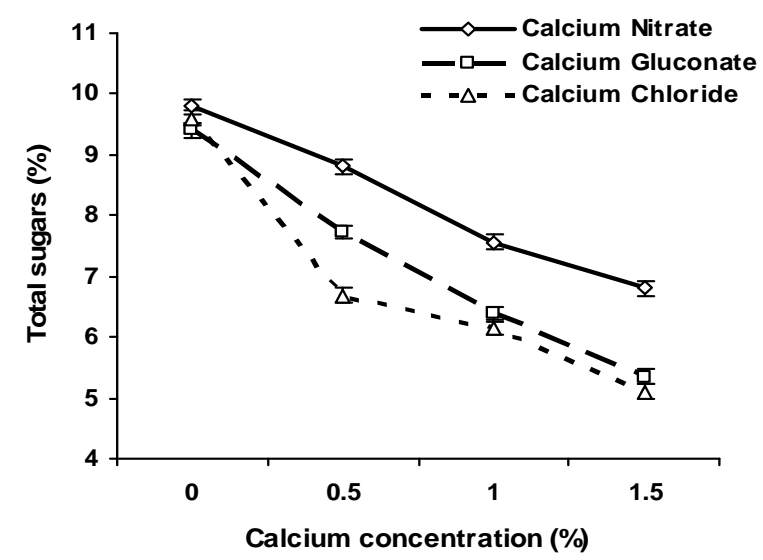

(c)

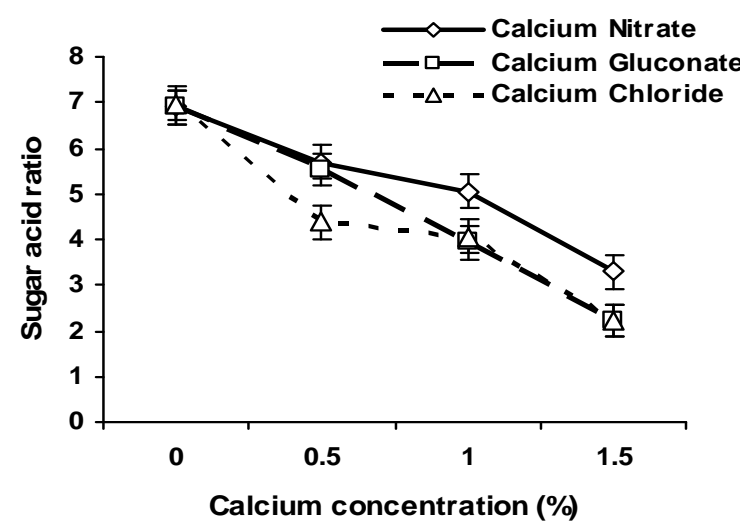

(e)

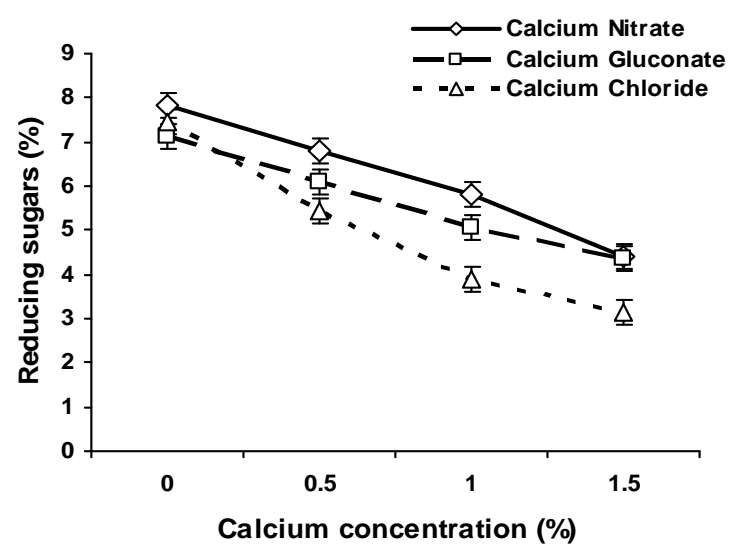

(b)

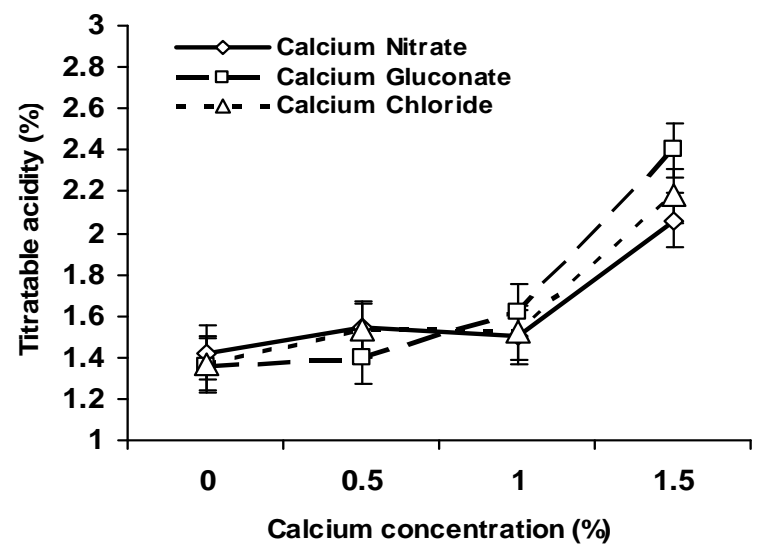

(d)

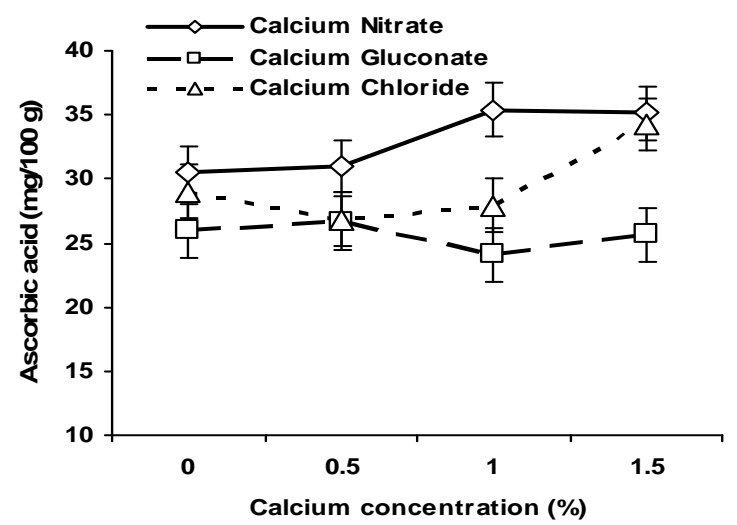

(f)

Fig. 2 (a) Total soluble solids (\%), (b) reducing sugars (\%), (c) total sugars (\%), (d) titratable acidity (\%), (e) sugar acid ratio and (f) ascorbic acid $(\mathbf{m g} / \mathbf{1 0 0} \mathrm{g})$ of strawberry fruits.

As treated with calcium nitrate, calcium gluconate and calcium chloride with $0 \%, 0.5 \%, 1.0 \%$ and $1.5 \%$ calcium concentration. Error bars represent $\operatorname{LSD}_{(0.05)}$.

distilled water (control) clearly demonstrates that calcium treatment decreases the ripening associated increase in TSS [49].

\subsection{Total Sugars (\%)}

The total sugars of strawberry fruits treated with different calcium salts, concentration of calcium as well as interaction of calcium salts and calcium concentration significantly affected the total sugars content of the fruits. The least total sugars (6.89\%) were recorded with the application of calcium chloride, followed by $7.22 \%$ in fruits treated with calcium 
gluconate, while the maximum total sugars (8.25\%) were recorded in fruit treated with calcium nitrate. The concentration of calcium also resulted in significant variation in total sugars of strawberry fruit with the minimum (5.75\%) in fruits treated with 1.5\% calcium which increased with decreasing calcium concentration to the maximum of $9.60 \%$ in control (Table 2). The interaction of calcium salts and concentration also significantly affected the total sugar content of strawberry fruits. The lowest total sugars contents of strawberry fruits $(5.10 \%)$ was recorded with the interaction of $1.5 \%$ concentration and calcium chloride, followed by $5.35 \%$ with $1.5 \%$ concentration and calcium gluconate while the highest total sugars $(9.80 \%)$ was recorded in fruits treated with distilled water (Fig. 2c). The total sugars in strawberry fruit gradually increased toward maturity [50] and during storage [39]. The total sugars of strawberries may increase up to $30 \%$ during storage [51]. Thus, most of the fruits, including strawberry show an increase in the concentration of sugars when ripening increases and further at storage [52]. Since calcium application delay the ripening in strawberry fruit during storage $[13,53]$. Thus calcium application at higher concentration is more effective in delaying ripening and retaining total sugars at certain lower levels [32].

\subsection{Titratable Acidity (\%)}

The titratable acidity (TA\%) of strawberry fruits was not significantly affected by different calcium salts, however concentration of calcium and the interaction of calcium salts and concentration significantly affected the titratable acidity of strawberry fruit (Table 2). The titratable acidity was the highest (2.21\%) in fruits treated with $1.5 \%$ calcium concentration, followed by $1.54 \%$ and $1.49 \%$ with $1.0 \%$ and $0.5 \%$ concentration with the difference being non significant between $1.0 \%$ and $0.5 \%$ calcium concentrations but both were significantly higher than control (1.38\%). The interaction of calcium salts and calcium concentrations revealed the highest titratable acidity (2.40\%) in strawberry fruits treated with $1.5 \%$ calcium gluconate, followed by $2.18 \%$ with $1.5 \%$ calcium chloride, while the least titratable acidity $(1.36 \%)$ was recorded with the application of distilled water (Fig. 2d). Generally, titratable acidity decreases while $\mathrm{pH}$ increases during storage [32] and reaches the lowest values during fruit senescence [8, 54]. Postharvest application of calcium salts retain the titratable acidity during storage [37], thus the highest titratable acidity at higher concentration (1.5\%) may be due to decrease in loss of organic acids and hence a decline in titratable acidity [32]. Among the different calcium salts, calcium gluconate at $1.5 \%$ concentration was more effective in retaining higher titratable acidity [33].

\subsection{Sugar Acid Ratio}

Calcium salts and calcium concentrations as well as the interaction of calcium salts and calcium concentration significantly affected the sugar acid ratio of strawberry fruits. The least sugar acid ratio (4.44) was in strawberry fruits treated with calcium chloride, followed by 4.65 with calcium gluconate, while the highest sugar acid ratio (5.23) was recorded with calcium nitrate treatment. Treatment of strawberry fruit with $1.5 \%$ calcium resulted in the minimum sugar acid ratio (2.61), followed by 4.35 with $1.0 \%$ calcium concentration. By contrast, sugar acid ratio was the highest (6.92) in fruits treated with distilled water (Table 2). The interaction of calcium salts and calcium concentrations resulted in the lowest sugar acid ratio (2.23) with calcium gluconate and calcium chloride at $1.5 \%$ concentration, followed by 3.29 with calcium nitrate at $1.5 \%$ concentration (Fig. 2e). A specific sugar/acid ratio is essential for characteristic flavor of a fruit and is used as a sign of edible maturity [11]. During the ripening process, the fruit acids are used in metabolism, while the sugar content increases [19], thus the sugar/acid ratio generally increases during storage due to further 
ripening $[55,56]$. The highest sugar acid ratio in control treatment could be due to more moisture loss and concentration of total sugars that increases sugar acid ratio [4]. Calcium chloride retained the lowest sugar acid ratio as compared to other sources of calcium during storage, it may be due to the reason that calcium chloride slow down the rate of respiration, moisture loss and further deteriorative oxidation reaction [37] as reported that calcium application retained sugar acid ratio of the fruits during cold storage [32]. At the initial stage of ripening, the sugar/acid ratio is low, because of low sugars and high fruit acid contents [57].

\subsection{Ascorbic Acid (mg/100 g)}

Different calcium salts, calcium concentration and the interaction of calcium salts and concentrations significantly affected the ascorbic acid content of strawberry fruits. The highest ascorbic acid content (32.99 mg/100 g) was in strawberry fruits treated with calcium nitrate, followed by $29.50 \mathrm{mg} / 100 \mathrm{~g}$ with calcium chloride while the minimum ascorbic acid content (25.58 mg/100 g) was with calcium gluconate treatment. Calcium concentration also significantly affected the ascorbic acid content of fruit with the maximum ascorbic acid (31.69 mg/100 g) in fruits treated with $1.5 \%$ salts concentration, followed by $29.12 \mathrm{mg} / 100 \mathrm{~g}$ with $1.0 \%$ while the minimum ascorbic acid content (28.13 mg/100 g) was in fruits treated with $0.5 \%$ calcium concentration (Table 2). The treatments interaction resulted in the highest ascorbic acid (35.35 mg/100 g), followed by 35.14 $\mathrm{mg} / 100 \mathrm{~g}$ in fruits treated with $1.0 \%$ and $1.5 \%$ calcium nitrate, respectively, with the difference being non significant. The least ascorbic acid content (24.07 $\mathrm{mg} / 100 \mathrm{~g}$ ) was recorded with $1.0 \%$ calcium gluconate (Fig. 2f). The vitamin $\mathrm{C}$ content generally decreases during storage [58] and the decrease could be as high as $50 \%$ [49]. Ascorbate oxidase is the major enzyme responsible for enzymatic degradation of ascorbic acid [59]. Extended storage, high temperature and low relative humidity enhance the loss of ascorbic acid [60]. Among the various calcium salts, calcium nitrate retained the highest ascorbic acid during storage may be due to reducing the rate of respiration and moisture loss [37]. Calcium salts concentration at $1.5 \%$ retained the highest ascorbic acid may be by delaying the overall ripening and senescence [13]. Lowering the loss of vitamin $C$ in strawberries, treated with high calcium concentration attributed to slowing down the respiration rate that delays the deteriorative oxidation reaction of vitamin C [6].

\section{Conclusions and Recommendations}

It can be concluded from this study that different calcium salts, calcium concentrations and the interaction of calcium salts and calcium concentrations significantly affected fruit quality and shelf life of strawberry. It retained the quality attributes by maintaining total soluble solids, reducing sugars, total sugars, titratable acidity, ascorbic acid, sugar acid ratio and overall acceptability. While all the calcium sources under study and calcium concentrations were effective in decreasing weight loss, retaining TSS and marketable fruits and extending the shelf life, calcium gluconate at concentration of $1.5 \%$ was more effective. Strawberry fruits should be dipped in calcium gluconate with calcium concentration of $1.5 \%$ for $30 \mathrm{~s}$ to retain quality and extend shelf life.

\section{References}

[1] Jouki, M., and Khazaei, N. 2012. "The Effect of Modified Atmosphere Packaging and Calcium Chloride Dipping on the Quality and Shelf Life of Kurdistan Strawberries.” J. Food Process Tech. 3 (10): 1-7.

[2] Park, I. S., Stan, D. S., Daeschel, A. M., and Zhao, Y. 2005. "Antifungal Coatings on Fresh Strawberries $($ Fragaria $\times$ ananassa) to Control Mold Growth during Cold Storage.” J. Food Sci. 70 (4): 202-7.

[3] Ali, A., Abrar, M., Sultan, M. T., Din, A., and Niaz, B. 2001. "Postharvest Physicochemical Changes in Full Ripe Strawberries during Cold Storage.” J. Animal and Plant Sci. 21 (1): 38-41. 
[4] Kader, A. A. 1991. "Quality and Its Maintenance in Relation to the Post Harvest Physiology of Strawberry." In The Strawberry into the 21st Century, edited by Dale, A., and Luby, J. J. Portland: Timber Press, 145-52.

[5] Brummel, D. A., and Harpster, M. H. 2001. "Cell Wall Metabolism in Fruit Softening and Quality and Its Manipulation in Transgenic Plants.” Plant Molecular Biology 47 (1): 311-40.

[6] Debeaufort, F., Quezada, J. A., and Voilley, A. 1998. "Edible Films and Coatings: Tomorrow's Packagings (A Review).” Crit. Rev. Food Sci. Nutr. 38 (4): 299-313.

[7] Lester, G. E., and Grusak, M. A. 2004. "Field Application of Chelated Calcium: Postharvest Effects on Cantaloupe and Honeydew Fruit Quality.” Hort. Tech. 14: 29-38.

[8] Garcia, M. A., Martino, M. N., and Zaritzky, N. E. 1998. "Plasticized Starch Based Coatings to Improve Strawberry Quality and Stability.” J. Agri. Food Chem. 46: 3758-67.

[9] Conway, W. S., Sams, C. E., Wang, C. Y., and Abbott, J. A. 1994. "Additive Effects of Postharvest Calcium and Heat Treatments on Reducing Decay and Maintaining Quality in Apples.” J. Amer. Soc. Hort. Sci. 119: 49-53.

[10] Mitchell, F. G. 1985. "Postharvest Handling Systems: Temperate Fruits.” In Postharvest Technology of Horticultural Crops. California: University of California Special Publication, 143-8.

[11] Rab, A., and Haq, I. 2012. "Foliar Application of Calcium Chloride and Borax Influences Plant Growth, Yield and Quality of Tomato (Lycopersicon esculentum Mill.) Fruit.” Turkish J. Agri. and Forestry 38: 553-62.

[12] Castello, M. L., Chiralt, A., and Fito, P. J. 2010. "Changes in Respiration Rate and Physical Properties of Strawberries due to Osmotic Dehydration and Storage.” J. Food Eng. 97 (1): 64-71.

[13] Asrey, R., and Jain, R. K. 2004. "Effect of Certain Post Harvest Treatments on Shelf Life of Strawberry CV. Chandler." In Proceedings of the 7th International Symposium on Temperate Zone Fruits in the Tropics and Subtropics, 696.

[14] Jan, I., Rab, A., and Sajid, M. 2013. "Influence of Calcium Chloride on Physical Characteristics and Soft Rot Incidence on Fruit of Apple Cultivars.” J. Animal \& Plant Sci. 23: 1353-9.

[15] Haq, I., Rab, A., and Sajid, M. 2013. "Foliar Application of Calcium Chloride and Borax Enhance the Fruit Quality of Litchi Cultivars.” J. Animal and Plant Sci. 23: 1385-90.

[16] Poovaiah, B. W. 1986. "Role of Calcium in Prolonging Storage Life of Fruits and Vegetables.” Food Tech. 40: 86-9.

[17] Cheour, F., Willemot, C., Arul, J., Makhlouf, J., and Desjardins, Y. 1991. "Postharvest Response of Two
Strawberry Cultivars to Foliar Application of $\mathrm{CaCl}_{2}$." Hort. Sci. 26 (9): 1186-8.

[18] Glenn, G. M., Reddy, A. S., and Poovaiah, B. W. 1988. "Effect of Calcium on Wall Structure, Protein Phosphorylation and Protein Profile in Senescing Apples.” Plant Cell Physiology 29: 565-72.

[19] Pilar, H. M., Almenar, E., Ocio, M. J., and Gavara, R. 2006. "Effect of Calcium Dips and Chitosan Coatings on Post Harvest Life of Strawberries (Fragaria ananassa)." Postharvest Biol. and Tech. 39 (3): 247-53.

[20] Atress, A. S. H., El-Mogy, M. M., Anean, E. E. A., and Alsannius, B. W. 2010. "Improving Strawberry Fruit Storability by Edible Coatings as a Carrier of Thymol or Calcium Chloride.” J. Hort. Sci. and Ornamental Plants 2 (3): 88-97.

[21] Batta, Y. A. 2007. "Control of Post Harvest Diseases of Fruit with an Invert Emulsion Formulation of Trichoderma Harzianum Rifai.” Post Harvest Biology and Technology 43 (1): 143-50.

[22] Hardenburg, R. E., and Anderson, R. E. 1979. "Effects of Post Harvest Calcium and Other Chemical Treatments on Softening, Scald, Bitter Pit and Breakdown of Stored Apples.” Hort. Abst. 49 (12): 790-9.

[23] Lara, I., Garcia, P., and Vendrell, M. 2004. "Modifications in Cell Wall Composition after Cold Storage of Calcium Treated Strawberry (Fragaria $\times$ ananassa) Fruit.” Postharvest Biol. and Tech. 34 (3): 331-9.

[24] Rauf, M. A., Zubair, M., Khan, J., and Ali, Z. 1998. "Effect of Different Levels of N.P.K. on the Yield and Growth of Strawberry Cv. Gorella.” Sarhad J. Agri. 14 (1): 27-8.

[25] Bhatti, M. A. 1995. Base Line Situation of Strawberry Production and Marketing-History of Strawberry Production. Project Publication No. 121.121, Malakand Fruit and Vegetable Development Project (MFVDP), Mingora, Swat, Pakistan.

[26] Han, C., Lederer, C., Mcdaniel, M., and Zhao, Y. 2005. "Sensory Evaluation of Fresh Strawberries Coated with Chitosan Based Edible Coatings.” J. Food Sci. 70: 172-8.

[27] Celikel, F. G., Kaynas, K., and Erenoglu, B. 2005. "A Study on Modified Atmosphere Storage of Strawberry." In Proceedings of the 24th International Horticultural Congress, Issues and Advances in Postharvest Horticulture, 628.

[28] Larmond, E. 1977. Laboratory Methods for Sensory Evaluation of Foods. Ottawa: Agriculture Canada.

[29] Association of Official Analytical Chemist (AOAC). "Official Methods of Analysis.” 18th ed., Washington, D.C., USA.

[30] Ayranci, E., and Tune, S. 2003. "A Method for the Measurement of the Oxygen Permeability and the 
Development of Edible Films to Reduce the Rate of Oxidative Reactions in Fresh Foods.” Food Chem. 80: 423-31.

[31] Zhang, M., Li, C. L., Huan, Y. J., Tao, Q., and Wang, H. O. 2001. "Preservation of Fresh Grapes at Ice-Temperature-High Humidity.” International Agro Physics 15: 139-43.

[32] Han, C., Zhao, Y., Leonard, S. W., and Traber, M. G. 2004. "Edible Coatings to Improve Storability and Enhance Nutritional Value of Fresh and Frozen Strawberries (Fragaria ananassa) and Raspberries (Rubus ideaus)." Postharvest Bio. and Tech. 33: 67-78.

[33] Aguayo, E., Jansasithorn, R., and Kader, A. 2006. "Combined Effects of 1-Methylcyclopropene, Calcium Chloride Dip and Atmospheric Modification on Quality Changes in Fresh-Cut Strawberries." Postharvest Biol. and Tech. 40 (3): 269-78.

[34] Jeong, S. K., Choi, J. M., Cha, K. H., Chung, H. J., Choi, J. S., and Seo, K. S. 2001. "Deficiency Symptoms, Growth Statistics and Nutrient Uptake of 'Nyoho' Strawberry Affected by Controlled Calcium Concentrations in Fertilizer Solution.” J. Korean Soci. Hort. Sci. 42 (3): 284-8.

[35] Naphun,W., Kawada, K., Matsui, T., Yoshida, Y., and Kusunoki, M. 2000. "Effects of Calcium Sprays on the Quality of 'Nyoho' Strawberries Grown by Peat Bag-Substrate Bench Culture.” Kasetsart J. Natural Sci. 32 (5): 9-14.

[36] Alzamora, S. M., Salvatori, D., Topia, M. S., Lopez-Malo, A., Chanes, J. W., and Fito, P. 2005. "Novel Functional Foods from Vegetable Matrices Impregnated with Biologically Active Compounds.” J. Food Eng. 67 (1-2): 205-14.

[37] Goodarzi, F. 2009. "Effect of Post Harvest Application of Calcium on Quality and Shelf Life of Strawberry.” J. Sci. and Tech. 46 (12): 231-40.

[38] Pilar, H. M., Almenar, E., Valle, V. D., Velez, D., and Gavara, R. 2008. "Effect of Chitosan Coating Combined with Postharvest Calcium Treatment on Strawberry (Fragaria $\times$ ananassa) Quality during Refrigerated Storage.” Food Chem. 110: 428-35.

[39] Pineli, L. L. O., Moretti, C. L., Santos, M. S., Campos, A. B., Brasileiro, A. V., Cordova, A. C., and Chiarello, M. D. 2010. "Antioxidants and Other Chemical and Physical Characteristics of Two Strawberry Cultivars at Different Ripeness Stages.” J. Food Comp. and Anal. 14: 27-35.

[40] Sistrunk, W. A., and Morris, J. R. 1985. "Strawberry Quality: Influence of Cultural and Environmental Factors.” In Evaluation of Quality of Fruits and Vegetables. Netherlands: Springer Netherlands, 217-56.

[41] Han, C., Lederer, C., McDaniel, M., and Zhao, Y. 2005. "Sensory Evaluation of Fresh Strawberries (Fragaria ananassa) Coated with Chitosan-Based Edible Coatings.” J. Food Sci. 70 (3): 325-9.

[42] Khosroshahi, M. R. Z., Ashari, M. E., and Ershadi, A. 2007. "Effect of Exogenous Putrescine on Postharvest Life of Strawberry (Fragaria ananassa) Fruit, Cultivar Selva.” Scientia Horticulture 114: 27-32.

[43] Ribeiro, C., Antonio, A., Vicente, A., Teixeira, J., and Candida, M. 2006. "Optimization of Edible Coating Composition to Retard Strawberry Fruit Senescence.” Postharvest Biol. and Tech. 44: 63-70.

[44] Wang, C. Y., Conway, W. S., and Abbott, J. A. 1993. "Postharvest Infiltration of Polyamines and Calcium Influences Ethylene Production and Texture Changes in Golden Delicious Apples.” J. Amer. Soci. Hort. Sci. 118: 801-6.

[45] Poovaiah, B. W. 1979. "Role of Calcium in Ripening and Senescence.” Soil Sci. and Plant Anal. 10: 83-101.

[46] Basson, C. E., Groenewald, J. H., Kossmann, J., Cronje, C., and Bauer, R. 2010. "Sugar and Acid Related Quality Attributes and Enzyme Activities in Strawberry Fruits.” Food Chemistry 121: 1156-62.

[47] Kafkas, E., Kosar, M., Paydas, S., Kafkas, S., and Baser, K. H. C. 2007. "Quality Characteristics of Strawberry Genotypes at Different Maturation Stages.” Food Chem. 100: 1229-36.

[48] Sturm, K., Koron, D., and Stampar, F. 2003. “The Composition of Fruit of Different Strawberry Varieties Depending on Maturity Stage.” Food Chem. 83 (3): 417-22.

[49] Cordenunsi, B. R., Nascimento, J. R. O., and Lajolo, F. M. 2003. "Physicochemical Changes Related to Quality of Five Strawberry Fruit Cultivars during Cool Storage.” J. Food Chem. 83 (2): 167-73.

[50] Kirad, K. S., Barche, S., Dash, A., and Sharma, R. K. 2007. "Response of Different Packaging Materials and Chemicals on the Shelf Life of Strawberry Fragaria ananassa Duch. and Correlation between Different Traits.” Acta Horticulture 746: 89-95.

[51] Cordenunsi, B. R., Genovese, M. I., Nascimento, J. R. O., Hassimotto, N. M. A., Santos, R. J., and Lajolo, F. M. 2005. "Effects of Temperature on the Chemical Composition and Antioxidant Activity of Three Strawberry Cultivars.” Food Chem. 91: 113-21.

[52] Mahmood, T., Anwar, F., Abbas, M., Boyee, M. C., and Saari, N. 2012. "Compositional Variation in Sugars and Organic Acids at Different Stages in Selected Small Fruits from Pakistan.” Int. J. Mole. Sci. 13: 1380-92.

[53] Cordenunsi, B. R., Nascimento, J. R. O., Genovese, M. I., and Lajolo, F. M. 2002. "Influence of Cultivar on Quality Parameters and Chemical Composition of Strawberry Fruits Grown in Brazil.” J. Agri. and Food Chem. 50: 2581-6. 
[54] Ghuoath, A. E., Arul, J., Ponnampalam, R., and Boulet, M. 1991. "Chitosan Coating Effect on Storability and Quality of Fresh Strawberry.” J. Food Sci. 56: 1618-20.

[55] David, O., Collin, S., Sievert, J., Fjeld, K., Doctor, J., and Arpaia, M. L. 2008. "Commercial Packing and Storage of Navel Oranges Alters Aroma Volatiles and Reduces Flavor Quality.” Postharvest Bio. and Tech. 47: 159-67.

[56] Muhammad, A. T., Tahir, F. M., Asi, A. A., and Pervez, M. A. 2011. "Effect of Curing and Packaging on Damaged Fruit Quality.” J. Biol. Sci. 1 (1): 13-6.

[57] Wozniak, W., Radajewska, B., Reszelska-Sieciechowicz, B., and Dejwor, L. 1997. "Sugars and Acid Content Influence Organoleptic Evaluation of Fruits of Six
Strawberry Cultivars from Controlled Cultivation.” Acta Horticulture 439 (1): 333-6.

[58] Biale, J. B. 1960. "The Postharvest Biochemistry of Tropical and Subtropical Fruits.” Advance Food Research 10: 293.

[59] Saari, N. B., Fujita, S., Miyazoe, R., and Okugawa, M. 1995. "Distribution of Ascorbate Oxidase Activities in the Fruits and Some of Their Properties." J. Food Biochem. 19: 321-7.

[60] Seung, K. L., and Kader, A. A. 2000. "Preharvest and Postharvest Factors Influencing Vitamin C Content of Horticultural Crops.” Postharvest Bio. and Tech. 20: 207-20. 